\title{
ECOLOGY-ECONOMIC ESTIMATION OF DAMAGE FROM WATER POLLUTION
}

Shandyba Alexander Borisovich

$\mathrm{PhD}$, Associate Professor

Sumy National Agrarian University ORCID: 0000-0003-3003-7173

email: Alexandrshandyba@gmail.com

Khursenko Svitlana Mykolaivna

Sumy National Agrarian University

ORCID: /0000-0001-6307-2042

email: khursenkosvetlana@gmail.com

Semernya Olena Volodymyrivna

Sumy National Agrarian University

ORCID: 0000-0002-0201-1294

email: semernya.olena@gmail.com

The society is suffering significant economic losses due to the incidence of human contamination with environmental pollution. There are two main steps to be taken when assessing damage and planning security measures: 1) direct calculation of various financial and other types of damage, and 2) marketing analysis with minimization of the cost-to-damage ratio. In the latter case, it is necessary to have not only a statistical database of pollution and morbidity monitoring, but also an acceptable optimization model with identified risks of exposure to hazardous pollution factors. In the approach proposed in the article, the procedure for estimation of damage and cost optimization is limited only by the granulation composition of mineral fertilizers and the water protection effect of the prolonged (slow) action of larger granules.

Keywords: environment, reservoir, water pollution, concentration background, migration, ecological and economic assessment, harmful components, mineral fertilizers.

DOI: https://doi.org/10.32845/msnau.2019.1-2.1

\section{Introduction}

The comparative ecological and economic efficiency of capital expenditures on water protection activities should be calculated already at the stage of planning agrochemical measures in crop production, introduction of new types of agricultural machinery, construction of new or reconstruction of existing irrigation systems.

The magnitude of the prevented economic damage from pollution of surface water bodies is determined according to a typical widespread methodology approved by leading economic and research institutions:

$W_{n}=\kappa \Phi M$,
where $\quad K-$ the numerical constant of damage, taken from environmental and economic considerations, estimated at approximately UAH 400 per tonne of pollutant;

$\Phi$ - the tariff constant of the self-cleaning power of the reservoir depending on the anthropogenic load on it and the climate zone;

$M$ - the mass of pollution prevented from getting to the reservoir is given.

In turn, the cited mass of prevented contamination $M$ is determined by the volume and toxicity of contaminants of different nature entering the reservoir due to migration:

$$
M=W \sum_{i=1}^{N} A_{i} m_{i}
$$

where $\quad W-$ the total amount of precipitation that caused the migration of contamination by volume $M$; reservoir;

$\mathrm{N}$ - the total number of contaminants migrating to the i - controlled contamination number;

$m_{i}-$ prevented mass of annual discharge of $i$-th pollution due to its migration;

$A_{i}$ - indicator of relative toxicity of discharge of $i$-th pollution to the reservoir.

And $A_{i}=\frac{1}{M P C_{i}}$ is defined as the ratio of some conditional toxic contamination with a single maximum permissible concentration of MPC to $M P C_{i}$ of the actual controlled contamination.

The estimated number of migratory contaminants in the soil-water system of agricultural land is consistent with the excess of the actual concentration of contamination above its permissible level for the control areas. For example, the calculation of the reduced mass for pollution "nitrogen" should be carried out on the indicator "total nitrogen" and the magnitude of the relative risk of migratory pollution.

2.Survey of the conducted researches in the field of pollution of reservoirs by migrating soluble toxic components. Setting the purpose and objectives of the work

One of the target elements of environmental safety is the system of assessment and analysis of the real concentration background of pollution and forecasting its changes over time. Based on the totality of such data, it becomes possible to calculate environmental and economic risks and support optimal management decisions [1-3].

The procedure for monitoring water quality in natural reservoirs provides for: 
- creation of geo-hydrodynamic and geochemical maps of coastal zones;

- determining the nature of economic activity in these zones;

- identification of existing and potential sources of pollution, especially disorganized ones;

- development of methods of collecting and processing of laboratory data of control sites, first of all, the most informative and indicative ones; analysis,

- management of monitoring data, including statistical

- interpretation, presentation and dissemination in information networks, including the general public $[12,13,14]$.

Due to the increase in the level of radiation hazard and the spread of landfills for toxic waste, the focus of research on the migration of mobile components concerned mainly the identification and analysis of contamination zones [4-5]. Physicochemical mechanisms of dissolution and leaching of moving components in soils have been considered in relation to granular mineral and organo-mineral fertilizers [6-8]. A laboratory procedure for studying the kinetics of the process of dissolving a granular product is presented in [9]. Hazard identification, risk assessment and prevention in terms of life safety are dedicated to work $[10,11]$.

It should be noted that the results of ecological and economic assessment of environmental pollution damage were calculated on the basis of different methods and often did not give good objective reasons for making management decisions $[6,11]$.

Thus, the presented study aims to develop an engineering approach to minimize environmental damage, in particular groundwater and surface water due to migration of soluble granular mineral fertilizer components. tilizers

3.Influence of particle size distribution of mineral fer-

To evaluate the effect of particle size distribution and solubility of mineral fertilizers, we will calculate the mass distribution of washed and migrating components. The peak height of $C_{\max }$ leaching curves is theoretically illustrated in Comparative Table
1 , which shows the relative migration characteristics of granules of different diameter $d$ (proportional to its cube $d^{3}$ ) and coefficient of mass yield (inversely proportional to the diameter) for the same agrotechnical rate of introduction and duration.

The identity of the rate of application of mineral fertilizers to soil idem granules of different sizes is substantiated by the equation of material balance:

$$
H=\rho n \frac{\pi d^{3}}{6}=i d e m \text {, }
$$

where $\quad H$-weight (norm) of the granules introduced per unit area;

$\rho$ - density of mineral fertilizer pellets;

$n$ - the number of granules with a diameter $d$ per unit area;

$d$-diameter of fertilizer pellets.

Taking $\rho=$ const, we obtain the identity of the rate of application of mineral fertilizers to the soil:

$$
\text { idem }=n d^{3} \text {. }
$$

It should be noted that with the same fertilizer application, the basic diameter of the $d=10 \mathrm{~mm}$ granules is 1.95 granules with a diameter of $8 \mathrm{~mm}, 4.63$ granules with a diameter of $6 \mathrm{~mm}$, 15.6 granules with a diameter of $4 \mathrm{~mm}$ and 125 granules with a diameter of $2 \mathrm{~mm}$. Given that the mass yield of the granules increases in proportion to the square of their diameter, the total amount of washed active substance involved in the migration along the relief of the control area to the reservoir will be determined by the product of the relative number of granules on the relative surface area of the granules. That is, the last row of Table 1 is the product of the second and third rows of this table. Obviously, for granules with a diameter of $2 \mathrm{~mm}$ with the same application rate and identical rainfall intensity under similar geo-hydrodynamic conditions, the relative amount of washed substance is 5 times higher than the same indicator for the basic size of $10 \mathrm{~mm}$.

Table 1

\section{Effect of granulometric composition of fertilizers on the relative}

\begin{tabular}{|c|c|c|c|c|c|}
\hline Diameter $d$ of granules, $\mathrm{mm}$ & 10 & 8 & 6 & 4 & 2 \\
\hline The relative weight of the granules, $\%$ & 100 & 51,2 & 21,6 & 6,4 & 0,8 \\
\hline The number of $n$ granules relative to the base diameter $d=10 \mathrm{~mm}$ & 1 & 1,95 & 4,63 & 15,6 & 125 \\
\hline The relative surface area of the granules & 1 & 0,64 & 0,36 & 0,16 & 0,04 \\
\hline The relative amount of washed substance & 1 & 1,25 & 1,67 & 2,5 & 5 \\
\hline
\end{tabular}

amount of washed substance $\%$ involved in the migration process

\section{Assessing the nature of migration and environmen-} tal damage

The analysis of migration curves showed the correlation of peak concentrations with the granulation composition of the fertilizers introduced (Fig. 1). The characteristics of migration of soluble components of mineral fertilizers in soil-water systems give grounds for agrochemical optimization and ecological and economic calculation of prevented damage to the environment.

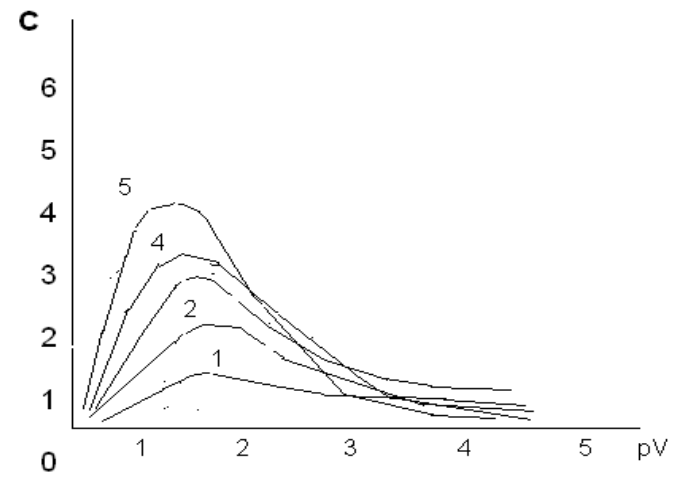

Fig. 1. The nature of the migration curves of the moving components depending on the particle size distribution of mineral fertilizers introduced: 1 - $10 \mathrm{~mm}, 2-8 \mathrm{~mm}, 3-6 \mathrm{~mm}, 4-4 \mathrm{~mm}, 5-2 \mathrm{~mm}$ 
As an example, we will evaluate the environmental and economic consequences of using the specified range of mineral fertilizers. To do this, we use the basic formula for environmental damage (1), where as $M$, the relative mass of contamination (soluble components of granular fertilizer), which is likely to enter the reservoir due to migration, we take the calculated data of table 1.

We transform the indicative schedule of ecological and economic analysis (Fig. 1) to the specific conditions of application of granular fertilizers in control areas of agricultural lands. The results of the analysis are shown in Fig. 2.

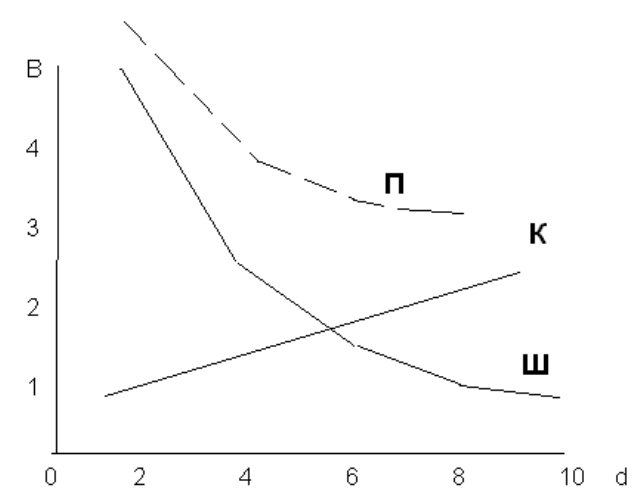

Fig. 2. The ratio of the present value of environmental protection measures $\Pi$, capital expenditures $\boldsymbol{K}$ and pollution damage $\boldsymbol{W}$ by migrating components of the introduced granular fertilizers of different diameter
The descending curve of the number of migratory components and the corresponding ecological and economic damage to the reservoirs depending on the particle size distribution is predominantly exponential in accordance with the values of the relative amount of washed substance (last row of Table 1). The increasing cost of producing granular fertilizers in the first approximation is approximated by a linear function. Thus, as a result of the interaction of two opposite tendencies, there is a reason to find the optimum particle size distribution of fertilizers of prolonged action and the costs associated with their production (Fig. 2).

\section{Conclusions}

The environmentally hazardous effects of the migration of toxic components of mineral fertilizers, the intensive contamination of agricultural areas and lands through the misuse of mineral fertilizers can be prevented by effective agrotechnical practices, environmental monitoring and the safe use of mineral fertilizers and pesticides.

In order to limit and minimize the movement of any component to groundwater or surface water, a long-term soil-ecological forecast should be made, including geochemical mapping based on computer simulation, together with an environmental and economic assessment of prevented damage.

\section{Reference:}

1. Надточій П.П. Екологія ґрунту та його забруднення / Надточій П.П., Германенко В.Г., Вольвач Ф.В. - К. : Аграрна наука, 1998. - 286 с.

2. Добрива та їх використання: Довідник. - К. : Арістей, 2010. -254 с.

за фін. підтримки ДП «АГРОЦЕНТР ЄВРОХІМ-УКРАЇНА».

3. Измайлов Р.Р., Голованова О.А. Биорезорбируемость гранулированного композита на основе карбонатгидроксилапатита и желатина в средах с различными значениями pH // Вест. Ом. ун-та. 2015. № 2. С. 61-65.

4. Шандиба О.Б. Застосування методів Ейлера та Лагранжа в прикладних задачах гідродинаміки // Вимірювальна та обчислювальна техніка в технологічних процесах. - № 2 (55). - 2016. - С. 181-185.

5. Шандиба О.Б., Шпетний Д.М. Моделювання динаміки концентраційного фону рухомих забруднень засобами EXCEL // Збірник наукових статей IX Міжнародної науково-практичної конференції „Екологічна безпека: проблеми і шляхи вирішення” (9-13 вересня 2013) - Алушта, 2013. - Т. 2. - С. 156-159.

6. Шандиба О.Б., Шандиба І.О., Курило А.О., Шпетний Д.М. Економічна ефективність впровадження заходів охорони праці та довкілля // Технічний сервіс агропромислового та транспортного комплексів. - № 5. - 2016. - С. 188-192.

7. Холин Б.Г., Шандыба А.Б., Хохлов Л.Г. и др. Расчет перфорированных оболочек центробежных и вибрационных грануляторов // Химическая промышленность. - № 4. - 1991. - С. 40-42.

8. Шандиба О.Б., Вакал С.В., Толбатов А.В., Смоляров Г.А. Еколого-технологічні аспекти виробництва та застосування гранульованих мінеральних добрив // Монографрія «Научное окружение современного человека». - 2018. - С. 147-155.

9. Данилов Д.Г. Экспериментальное исследование процесса растворения гранулированного коагулянта // Вестник ИГЭУ, вып. 2, 2008, С.1-4.

10. Шандиба І.О., Кузема О.С., Шандиба О.Б. Оцінювання впливу виробничих фракторів на рівень техногенної безпеки // Матеріали VI Міжнародної науково-практичної конференції «Екологічна безпека: проблеми і шляхи вирішення»: - Т.2. - 2010. - C. 147-150.

11. Идентификация опасностей, оценка рисков и управление рисками [Електронний ресурс] // Услуги по охране труда и безопасности в Беларуси и Минске - Режим доступу: http://helper.by/identifikaciya-opasnosteie-i-ocenka-riskov-upravleni.html.

12. A.B.Shandyba, D.M.Shpetny. Pollution migration forecast for soil geochemistry mapping // Geomatics, Landmanagement and Landscape. - № 3. - Poland, Krakow. - december 2015. - P. 101-112.

13. D.Han, X.Tong, M.G.Kurrel, G.Cao, M.Jin, C.Tong. Evalution of the impact on uncontrolled landfill on surrounded groundwater quality- Journal f Geochemical Exploration (2013), Elsevier-com. 
14. D.Russo, A.Laufer, A.Silber, S.Assouline. Water up take, active root volume and solute leaching drip irrigation: A numerical study. - Water resources research, vol.45., W12413, 2009.

\section{Шандиба О.Б., Хурсенко С.М., Семерня О.В.}

ПРОВЕДЕННЯ ЕКОЛОГО-ЕКОНОМІЧНОЇ ОЦІНКИ ШКОДИ ВІД ЗАБРУДНЕННЯ ВОДОЙМ

Суспільство зазнає суттєвих економічних втрат внаслідок захворюваності людей при забрудненні довкілля. При оцінюванні завданих збитків та плануванні заходів безпеки прийнято виділяти два основних етапи: 1) прямий підрахунок різноманітної фінансової та інших видів шкоди та 2) маркетинговий аналіз з мінімізацією співвідношення „витрати - попереджена шкода". В останньому випадку необхідно мати не лише статистичну базу даних моніторингу забруднення та захворюваності, але й прийнятну оптимізаційну модель з визначеними ризиками прояву небезпечних фракторів забруднення. У запропонованому у статті підході процедура оцінювання шкоди та оптимізації витрат обмежується лише грануляційним складом мінеральних добрив та водоохоронним ефектом пролонгованої (уповільненої) дії більш крупних гранул.

Ключові слова: довкілля, водойма, забруднення води, концентраційний фон, міграція, еколого-економічна оцінка, шкідливі компоненти, мінеральні добрива.

\section{Шандыба А.Б., Хурсенко С.Н., Семерня Е.В.}

ПРОВЕДЕНИЕ ЭКОЛОГО-ЭКОНОМИЧЕСКОЙ ОЦЕНКИ УЩЕРБА ОТ ЗАГРЯЗНЕНИЯ ВОДОЕМОВ

Общество испытывает существенные экономические потери вследствие заболеваемости людей при загрязнении окружающей среды. При оценке нанесенного ущерба и планировании мер безопасности принято выделять два основных этапа: 1) прямой подсчет разнообразного финансового и других видов ущерба и 2) маркетинговый анализ с минимизацией соотношения «затраты - предупрежденный ущерб". В последнем случае необходимо иметь не только статистическую базу данных мониторинга загрязнения и заболеваемости, но и приемлемую оптимизационную модель с определенными рисками проявления опасных факторов загрязнения. В предложенном в статье подходе процедура оценки ущерба и оптимизации расходов ограничивается только грануляционным составом минеральных удобрений и водоохранным эфрфектом пролонгированного (замедленного) действия более крупных гранул.

Ключевые слова: окружающая среда, водоем, загрязнение воды, концентрационный фон, миграция, эколого-экономическая оценка, вредные компоненты, минеральные удобрения.

Дата надходження до редакції: 14.02.2019 